Прудникова, Тетяна. «Функціонування неспеціалізованих лексем в публіцистичних текстах економічної тематики». Лінгвостилістичні студії, вип. 11, 2019, с. 145-54.

Prudnykova, Tetiana. "Non-specialized Lexical Units Functioning in the Publicistic Texts on Economic Topics". Linguostylistic Studies, iss. 11, 2019, pp. 145-54.

Удк 81'373.46:33

https://doi.org/10.29038/2413-0923-2019-11-145-154

\title{
ФУНКЦІОНУВАННЯ НЕСПЕЦІАЛІЗОВАНИХ ЛЕКСЕМ В ПУБЛІЦИСТИЧНИХ ТЕКСТАХ ЕКОНОМІЧНОЇ ТЕМАТИКИ
}

\author{
Тетяна Прудникова \\ Кримський інженерно-педагогічний університет, \\ Сімферополь, Україна
}

У статті на матеріалі публіцистичних текстів проаналізовано найуживаніші неспеціалізовані лексеми економічної сфери, що означають дії, процеси та стани, пов'язані з грішми, визначено функціонально-стилістичні характеристики цих лексем у мові сучасних засобів масової комунікації, простежено тенденції розширення групи економічної лексики завдяки номінаціям інших тематичних груп. Докладно схарактеризовано стилістичну роль неспеціалізованих лексем в економічній тематиці, наголошено на негативній оцінці в мові сучасних масмедійних жанрів.

Ключові слова: лексеми економічної сфери, неспеціалізовані лексеми, лексичне значення, мова засобів масової комунікації, стилістична роль.

\section{NON-SPECIALIZED LEXICAL UNITS FUNCTIONING IN THE PUBLICISTIC TEXTS ON ECONOMIC TOPICS Tetiana Prudnykova}

Crimean State Engineering Pedagogical University, Simferopol, Ukraine

The article analyzes the non-specialized lexical units, most commonly used in the economic discourse, which denote actions, processes, and states related to money. The study identifies functional-stylistic features of these lexical items in the texts of modern mass media and traces an enlargement of the economic lexical group by means of the lexemes from other thematic groups. The article describes the stylistic role of the non-specialized lexical items in the topics on economics with an emphasis on their negative assessment in the language of modern mass media genres.

The purpose of the article is to analyze non-specialized economic vocabulary in the Ukrainian mass media against the background of social dynamics, to substantiate a functionalstylistic diffuseness of vocabulary as one of the defining tendencies in the development of the Ukrainian language.

The material of the research is a body of lexical items, selected from the language of national and regional mass media. The descriptive research method and observation method were used as basic in this scientific research. At different stages of the research, the method of functional analysis was used to determine the stylistic load of lexical items and the comparative method - to analyze individual lexical positions, which are used in different styles of Ukrainian literary language.

(c) Прудникова Т., Східноєвропейський національний університет імені Лесі Українки, 2018.

Це стаття відкритого доступу на умовах CC BY-NC 4.0 
The article concludes that the use of lexical items with a figurative meaning for denoting economic actions, processes, and states has increased in the language of modern Ukrainian mass media. The updating of the economic vocabulary is caused by the influence of various extralinguistic factors. For the most part, the meaning of lexical units is related to wasting or total loss of money. Such linguistic items in economic topics are classified as nonspecialized lexical items, that is, belonging to different lexical-semantic groups and used in their figurative meaning. Non-specialized lexical items are mostly related to the verbs of physical action, usually stylistically marked, correlated with the informal style, and have a distinct pejorative coloring. With the help of the negative-assessed lexical items, the authors create appropriate vivid characteristics of those, who enrich at the expense of others, wasting money and committing fraud. The analyzed lexical items reflect the negative processes in the economic life of society and also confirm the progression of the tendency of non-specialized lexical items functioning in the economic topics.

The prospect of further research concerns the study of lexical units of other lexical and semantic groups, which will expand the study of the non-specialized economic vocabulary of the Ukrainian media against the background of social dynamics.

Key words: lexical items of economic field, non-specialized lexical items, lexical meaning, mass media language, stylistic role.

Вступ. В останні десятиліття в сучасному українському суспільстві інтенсивно розвинулися різні види економічної діяльності. Особливо активно почали здійснюватися процеси 3 грішми як між установами, організаціями, підприємствами, фірмами різних форм власності, так і між громадянами в приватному житті. Повсякденна увага українських засобів масової комунікації до цих процесів істотно сприяє популяризації економічної тематики, а лексеми, що їх позначають, стають широковживаними серед носіїв мови.

Активне функціонування лексем економічної сфери в XXI ст. у мові засобів масової комунікації зумовлене дією позамовних чинників: постійному обігу іноземна валюта, тривають торговельні відносини як у державі, так і на міжнародному рівні, розпочалася монетизація субсидій та пільг тощо. Тому простежуємо тенденцію до вживання як нових назв, так і тих, що перебували в пасивному словникові. У мові засобів масової комунікації активізувалася лексика інших галузей та сфер, яку використовують в економічній тематиці. Це засвідчує передусім те, що в сучасному лексиконі відбуваються міжстильові проникнення мовних одиниць, які потребують додаткових досліджень.

Мета статті - проаналізувати неспеціалізовану економічну лексику українських засобів масової комунікації на тлі соціальної динаміки, обгрунтувати функціонально-стильову дифузність лексики як одну 3 визначальних тенденцій у розвитку української мови.

Матеріал і методи дослідження. Матеріалом дослідження $\epsilon$ корпус лексем, дібраних із мови всеукраїнських та регіональних засобів масової комунікації. У статті використано як основні метод спостереження та описовий метод. На різних етапах дослідження послуговувалися методом функціонального аналізу для визначення стилістичного навантаження 
лексичних одиниць. Порівняльний аналіз окремих лексичних позицій, зафіксованих у різних стилях української літературної мови, виконано за допомогою зіставного методу.

Результати дослідження та дискусія. Про актуальність економічної тематики свідчать наукові розвідки дослідників української мови, які виокремлюють слова на позначення сучасних економічних реалій суспільства. Соціально-економічну лексику аналізують як терміни, так i загальновживані одиниці за частиномовною належністю (Воловик; Навальна; Стишов; Становлення; Чорновол), як фахову мову (Дружбяк), а також подають лексику з погляду структурно-типологічного аспекту (Михалевич; Чуєшкова), за походженням (Рудакова), розглядають економічну лексику в мовній картині світу українців (Кушмар) та в інших мовах (Лотка; Подвойська). Економічні терміни ставали предметом вивчення на матеріалі епістолярних текстів [Богдан]. Цікавий висновок дослідниці M. І. Навальної, яка вважає, що для одного контексту значення лексем $\epsilon$ прямим, для іншого - непрямим, що слугує підставою для поділу їх у межах спільної семантичної сфери на спеціалізовані й неспеціалізовані одиниці. Серед неспеціалізованих - лексеми різних лексико-семантичних груп, для яких значення «виконувати дію, пов'язану з грішми» $\epsilon$ здебільшого переносним. У спеціалізованих дієслів це значення переважно стилістично нейтральне, у неспеціалізованих - стилістично марковане, співвідносне $з$ розмовним стилем, та має виразне негативнооцінне чи фамільярне забарвлення (Навальна, «Семантико-стилістичні» 334).

Переважно основу економічної лексики становлять стилістично нейтральні одиниці та терміни, але, окреслюючи межі цієї групи слів, не можна обмежуватися одиницями тільки з основним значенням, така б класифікація була б не повною (Кузнецова 11). Тому погоджуємося 3 мовознавцями, що в групах лексем немає чітких меж, визначеної кількості, для лексичної системи характерні процеси взаємоперетину й взаємопроникнення (Кузнецова 10).

Спостерігаємо тенденцію, що в економічній тематиці мови українських засобів масової комунікації активізувалося вживання лексем, для яких значення $\epsilon$ переносним.

Дієслово горіти /згоріти має пряме значення «піддаватися дії вогню, знищуватися вогнем, гинути у вогні» (Словник 2: 130), що зазвичай засвідчує мова засобів масової комунікації, напр.: У нас усе згоріло... документи, одяг... Нічого не залишилося. Ми з сином практично просто неба, а допомоги чекати ні від кого... (www.0352.ua, 20.07.2016) (далі після цитати буде подано покликання на її джерело: сайт та дату публікації матеріалу); Дерев'яний будинок, від якого лишилися одні стіни, згорів у Костополі цього понеділка, 22-го вересня. У ньому проживало одинадиятеро осіб, у тому числі четверо дітей. Кореспондентам Суспільного погорільці розповіли, що згоріли побутові речі, одяг, документи (www.rv.suspilne. media, 22.09.19). 
Вогонь може знищувати й речі, що стосуються економічної сфери (гроші згоріли, купюри згоріли), але значення таких дієслів також $є$ прямим, пор.: Коли в будинку стається пожежа, перше, про що думають господарі взяти все найнеобхідніше та вибігти з вогняної пастки. Речей та меблів, знищених полум'ям уже не повернути. А от якщо згоріли гроші, відшкодувати їх можна. Фахівець Національного банку - Віталій Ковтонюк показує чорні згортки. Це гривневі купюри, що згоріли в одному з будинків Івано-Франківська. Залишки купюр фахівці дослідили й відшкодували власнику гроші (www.changeua.com, 27.10.2018).

Спостерігаємо тенденцію до активного вживання дієслово горіти / згоріти в мові українських засобів масової комунікації в переносному значенні «повністю втрачати/втратити», яке не зафіксоване в «Словнику української мови». Словник із переносних значень подає тільки частково наближене переносне, розмовне «зазнавати невдачі в якій-небудь справі //не виконуватися, не здійснюватися» (Словник 2: 130). В економічній тематиці дієслово горіти/згоріти вживають 3 іменником гроші, що позначають повну їхню втрату. Напр.: Гроші Києво-Печерської лаври згоріли в банку - митрополит Павел (www.religions.unian.ua, 23.03.2018); Всі гроші, які популярний режисер збирав на зйомки нових серій відомого кіножурналу, згоріли (www.segodnya.ua, 24.09.2015); Потім проводжають літніх людей додому та розповідають ту ж казку: пам'ятаєте, як у 90-х «згоріли» всі гроші, ось і скоро так буде, потрібно міняти (www. pokrovsk.city.ua); Може, якби на депозитах згоріли гроші президента, то прокуратура й суди заворушилися б, а тут - роботяги, за яких і слово замовити нікому (www.persha.kr.ua, 22.08.2018); Гроші, що мали піти на облаштування КПВВ на адмінкордоні з Кримом, «згоріли» минулого року - Мінфін (www.zmina.info, 15.01.2019); Для того, щоб гроші не «згоріли» у випадку обвалу якогось ринку, їх, так би мовити треба акумулювати... (https://www. hromadske.ua, 11.03.2019); «Ми пропонували, щоб ці гроші, які не дали торік, - дофінансували в наступному, бо це справедливо. Але ці гроші не дали і вони згоріли...» (www.samopomich.ua, 22.11.2018); Близько 60 тисяч гривень втратили четверо мешканців... Лише коли "співробітники банку» подзвонили і сказали, що треба перевести ще 2 тисячі, аби раніше перераховані гроші не «згоріли»... (www.pokrovskpolice.dn.ua, 18.03.2019) та ін.

Здебільшого в публіцистиці автори, використовуючи дієслова в переносному значенні, наголошують на цілковитій втраті коштів та безвиході пересічних українців, на шахрайській поведінці високопосадовців та підкреслюють зневагу до тих, хто спричинив втрату грошей.

Із дієсловом горіти/згоріти фіксуємо вживання іменників депозити та вклади, які журналісти використовують як у заголовкових комплексах, так і в текстах, пор.: У збанкрутілому російському банку «згоріли» депозити VIP... (заг.). У державного російського Агентства зі страхування вкладів «згорів» депозит на 850 млн рублів у збанкрутілому 
«Внєшпромбанку» (www.tsn.ua, 29.04.2016); «Згоріли» вклади - за комунальні борги. Хто не встигне до 15 листопада, той спізниться (www.vn.20minut.ua, 16.09.2005); Ощадбанк підрахував кількість вкладників Ощадбанку СРСР, які вже... отримали компенсації, бо вклади «згоріли»... (www.ua.korrespondent.net, 2.08.2018); Держава Україна виплатила тоді громадянам, вклади, які «згоріли» при СРСР, загалом близько 6 млрд. грн. (https://www.poltava.to, 10.04.2012). Словосполуку вклади згоріли в публікаціях на тему вкладів «Ощадбанку СРСР» дослідники активно фіксували в попередні десятиріччя, саме в той час проводили компенсаційні виплати (Навальна, «Семантико-стилістичні» 328-329). Ми ж засвідчуємо тяглість тенденції у функціонуванні цих неспеціалізованих лексем в економічній тематиці.

Дієслово палити/спалювати в різних стилях української мови зазвичай використовують в прямому значенні «піддавати дії вогню, знищувати вогнем» (Словник 9: 486), напр.: Спалили будинок Гонтаревої (заг.). Будинок колишньої голови Національного банку України Валерії Гонтаревої в селищі Гореничі під Києвом спалили в ніч на 17 вересня (www.epravda.com.ua, 17.09.2019).

У сучасних засобах масової комунікації простежуємо активне вживання дієслово палити/спалювати в економічній тематиці 3 іменником гроші в переносному значенні «знищувати, руйнувати, розвіювати» (Словник 9: 486), напр.: 3 року в рік, українці «спалюють гроші» - свої чи державні (субсидії) - відмовляючись від енергоефективного споживання енергії (www.uk-ua.facebook.com, 12.08.2019); Бюджетні гроші «спалили» в котлі (заг.). Стартує опалювальний сезон. Для двох навчальних закладів Сум він мав би бути третім сезоном на пелетах замість газу... (www.youtube.com, 12.08.2019); Микита Кадан: Мистецтво спалює гроші, а не заробляє... на здобуття Національної премії 2020 (www.knpu.gov.ua, 23.07.2019).

Використовуючи словосполуку спалювати гроші, журналісти таким чином привертають увагу до теми енергозбереження, економії в різних побутових та державницьких справах.

Дієслово палити/спалювати функціонує також в публіцистиці в сполученні з іменниками рублі, заощадження, копійка та ін., пор.: Росіянин спалив півтора мільйона рублів власних... (заг.). У російському місті Брянськ чоловік випадково спалив власні заощадження. Гроші він збирав на покупку квартири. Про інцидент у банку розповів журналістам... (www.tsn.ua, 19.04.2019); Насправді вміння планувати заощадження й контролювати власні витрати є важливим... Лампочки, які працюють серед ясного дня, спалюють копійку за копійкою (www.work.ua, 12.09.2019); Фінансовий аналітик - про кризи, збереження заощаджень Tesla... ще більш ризиковано, ніж Україна. Компанія спалює капітал (www.mind.ua, 31.05.2019). 
Аналізовані словосполуки зазвичай характеризують погану господарську діяльність осіб чи організацій та фірм, журналісти таким чином зауважують на ефективності в різних видах робіт тощо.

Дієслово їсти/з'їдати зазвичай у публіцистиці та інших стилях вживають у прямому значенні «споживати їжу» (Словник 9: 60), напр.: Дієтолог радить з'їдати приблизно таку кількість за кожен прийом їжі... (www.np.pl.ua, 4.07.2019).

У мові засобів масової комунікації фіксуємо активне використання лексеми в переносному значенні «повністю втрачати що-небудь (гроші)» (Словник 9: 581), напр.: Пожежа у «Вікторії»: скандальний дитячий табір продовжує «з'їати» бюджетні гроші, батьки впевнені, що не всі винні покарані (www.bloggers4gg.org.ua, 27.08.2018); Якщо автовиробник продовжить «з'їати» гроші такими темпами, то в 2018 році без додаткового фінансування він залишиться без готівки... (www.aspi.com.ua, 23.06.2018).

Прямі значення зі словом з'̈̈ати здебільшого не виражають дій із грішми чи іншими економічними складниками, а переносні передають опосередковані дії об’єктивної дійсності (Навальна, «Гроші», 107).

У публікаціях економічної тематики в значенні «втрачати гроші» дієслово з'їдати автори поєднують з іменниками кошти, інфляція, оплата, проценти та ін. Такі словосполуки зазвичай передають зайве витрачання коштів, неекономне використання грошей, пор.: Застарів смартфон, не морозить холодильник, ремонт в квартирі почав «з'̈дати» більше коштів, ніж очікувалося, а зайвих грошей уже немає... (www.news.maanimo.com, 28.03.2019); Але із зарплати фельдшерки, яку на початку 90-х ще й почала з'їдати інфляція... (www.books.google.com.ua, 23.02.2018); ...питання зниження витрат $i$ збереження грошей $\epsilon$ надзвичайно важливим... У середньому, оплата квартири в Лондоні може з'їдати до 70\%... (www.epravda.com.ua, 10.04.2018)

Нерідко в публіцистиці лексеми 3 переносним значенням виокремлюють лапками, що певною мірою підкреслює контраст загальновживаної лексики і лексики з додатковим переносним значенням. Це засвідчує, що переносне значення остаточно не усталилося в сучасній українській мові.

За спостереження М. І. Навальною (Навальна, «Гроші» 106), у мові сучасних засобів масової інформації активізувалася розмовна лексема заморожувати / заморозити з переносним значенням «тримати щонебудь невикористаним, лишати без застосування», що спричиняє відповідну або повну втрату грошей (Словник 3: 220), пор. пряме значення «сильно охолоджуючи, доводити до замерзання» (Словник 3: 220), напр.: заморозити гроші, заморозити фонди, заморозити мільйони та ін. Пор.: Гроші українців у «Webmопеу» заморозили до 2021 року (www.volynnews.com, 29.05.2018); Білий дім заморозив фонди. Проводить ревізію. Гроші не можна використовувати поки Держдепартамент не 
закінчить розбиратися (www.podrobnosti.ua, 23.10.2019); Ліхтенштейн заморозив 300 мільйонів офшору дружини судді Вищого госпсуду (www.nashigroshi.org, 3.09.2015). Словосполуки 3 дієсловом заморожувати / заморозити передають невпевненість членів спільноти у фінансових та банківських операціях, а також орозмовлюють публіцистику.

Дієслово конкретної фізичної дії осідати «опускаючись, покривати собою поверхню чого-небудь (про сніг, іній, пил і т. ін.)» (Словник 5: 763) в економічній тематиці функціонує переважно в переносному значенні «залишатися, розміщуватися, влаштовуватися де-, в кого-небудь» (Навальна, «Семантико-стилістичні» 333). У такому разі здебільшого йдеться про привласнення чогось (грошей) зазвичай неправомірним чи шахрайським шляхом, чого не фіксує «Словник української мови». У мові сучасних засобів масової комунікації цю лексему використовують 3 іменником гроші, напр.: Гроші за стоянку осідають у кишенях паркувальників (www.golos.com.ua, 1.02.2018); Але зараз гроші осідають 8 кишенях злодіїв (www.prm.ua, 9.08.2019); Дрібні гроші осідають у комерційних банках (www.rivnepost.rv.ua, 10.10.2019); Гроші осідають $в$ Сінгапурі і там вони діляться між Російською верхівкою, гаманцями Володимира Путіна, - повідомив Айсултан (www.ukranews.com, 1.08.2019); ...через корупцію гроші осідають в кишенях тих, хто у владі... (www.dt.ua, 23.05.2018).

Зазвичай у мові засобів масової комунікації контекст зі словосполукою гроші осідають передає осуд керівників та чиновників різних інституцій, недовіру до банківських та кредитних установ, характеризує недоброчесних працівників тощо.

Лексема зависати «зачепившись за що-небудь, тримаючись на чомунебудь, повисати, висіти» (Словник 3: 48) в економічній сфері здебільшого функціонує в переносному значенні, що позначає переважно незаконне, нахабне привласнення грошей чи припинення виплат через різні причини. Напр.: «Беззаперечною підставою для визнання заборгованості безнадійною, зокрема і щодо грошей, що «зависли» в ліквідованому банку... (www.ips.ligazakon.net, 16.04.2019); Гроші на виплату заборгованої зарплати гірникам «зависли» в банку (www. leopolis.news, 14.06.2019).

У сучасній публіцистиці фіксуємо й інші дієслова фізичної дії (nадати, захитатися, обвалитися, стрибнути), які в економічній тематиці позначають переносне значення «переміщення, зміну чогось», пор.: Гривня «впала». Тимчасово чи назавжди? (www.ukrinform.ua, 3.10.2019); Чому падає гривня. Три варіанти (www.nv.ua, 1.03.2016); Чому захиталася гривня: експерти пояснили ситуацію на валютному ринку (www.dostyp.com.ua`novini, 2.08.2018); Чому захиталася зміцніла гривня... (www.segodnya.ua, 12.09.2018); Варто панікувати? В обмінниках різко обвалилася гривня (www.vgolos.com.ua, 5.07.2018); Долар на міжбанку «стрибнув» до 28,09 гривні (www.epravda.com.ua, 28.08.2018). 
Подекуди речення, ужиті в засобах масової інформації, містять низку інших дієслів, хоча й менш частотних: спотикається, шкандибає, напр.: Гривня хитається, падає, спотикається $\boldsymbol{i}$ шкандибає далі. I вже незрозуміло, чи має вона управлятися, як зазвичай, в ручному режимі... (www.nv.ua, 1.03.2016).

Дієслова 3 переносним значенням зазвичай характеризують нестабільний і мало прогнозований курс валют в Україні, передають несприятливий економічний клімат для інвестицій, невпевненість українців у збереженні своїх заощаджень тощо.

Висновки та перспективи дослідження. Отже, у мові сучасних українських засобів масової комунікації помітно активізувалося вживання лексем із переносним значенням на позначення економічних дій, процесів та станів. Актуалізація економічної лексики зумовлена впливом різних позамовних чинників. Здебільшого значення лексем пов'язане 3 витрачанням, повною втратою коштів. Такі мовні одиниці в економічній тематиці зараховуємо до неспеціалізованих, серед яких здебільшого дієслова фізичної дії, зазвичай вони стилістично марковані, співвідносні 3 розмовним стилем та мають виразне пейоративне забарвлення. За допомогою вказаних негативнооцінних лексем автори створюють відповідні характеристики тих, хто збагачується коштом когось, марно витрачає гроші, здійснює шахрайські дії.

Аналізовані лексеми віддзеркалюють негативні процеси в економічному житті суспільства, а також засвідчують тяглість лінгвістичних тенденції у функціонуванні неспеціалізованих лексем економічної тематики.

Уживання слів із переносним значенням у публіцистиці засвідчує функціонально-стильову дифузність лексики як одну з визначальних тенденцій у розвитку української мови.

Перспективу подальших наукових пошуків убачаємо в дослідженні лексем інших лексико-семантичних груп, що розширить вивчення неспеціалізованої економічної лексики українських засобів масової комунікації на тлі соціальної динаміки.

\section{Список використаної літератури}

Богдан, Світлана. «Регулятив гроші в епістолярних текстах Лесі Українки». Лінгвостилістичні студії, вип. 6, 2017, с. 33-53.

Воловик, Лариса. Словотвірний потенціал префіксальних дієслівних економічних термінів у сучасній німещькій мові: структурно-семантичний і функціональний аспект. Автореф. дис. ...канд. філол. наук: 10.02.04. Херсон, 2012.

Дружбяк, Світлана. Термінотворча динаміка фахової мови економіки: структурносемантичний та функціональний аспекти (на матеріалі лексикографічних джерел і сучасної періодики Німеччини). Автореф. дис. ...канд. філол. наук: 10.02.04. Київ, 2010.

Кузнецова, Эра. «О принципах и методах выделения объема семантических классов русских глаголов». Классы и их взаимодействие. Свердловск, 1979, с. 5-12. 
Кушмар, Леся. Лексика економічної сфери в мовній картині світу українців. Автореф. дис. ...канд. філол. наук: 10.02.01. Луганськ, 2011.

Лотка, Олена. Англомовна термінологія фінансово-економічних взаємин. Автореф. дис. ...канд. філол. наук: 10.02.04. Київ, 2000.

Михалевич, Ольга. Структура та функції економічної лексики другої половини ХХ початку XXI століття. Автореф. дис. ...канд. філол. наук: 10.02.01. Луцьк, 2011.

Навальна, Марина. «Гроші можуть “згоріти”, їх можуть і “заморозити” (семантична динаміка дієслів у сучасній українській публіцистиці)». Культура слова, вип. 78, 2013, с. 104-109.

Навальна, Марина. Дієслівна лексика соціально-економічної сфери (на матеріалі мови засобів масової інформації кінця ХХ ст.). Переяслав-Хмельницький, 2002.

Навальна, Марина. «Семантико-стилістичні вияви дієслів економічної сфери в мові сучасної газетної періодики». Мовознавчий вісник, вип. 8, 2009, с. 326-35.

Подвойська, Оксана. Термінологія соціальної ринкової економіки в сучасній німецькій мові: номінативний та функціональний аспекти. Автореф. дис. ...канд. філол. наук: 10.02.04. Одеса, 2008.

Рудакова, Тетяна. Функціонування соціально-економічної лексики англомовного походження в українських засобах масової інформації кінця XX - початку XXI cm. Автореф. дис. ... канд. філол. наук: 10.02.01. Луганськ, 2009.

Словник української мови, за ред. І. К. Білодіда. В 11 т. Київ: Наукова думка, 1970-1980.

Становлення та нормування української економічної термінолексики. Харків, 2011.

Стишов, Олександр. Українська лексика кінця XX століття (на матеріалі мови засобів масової інформації). Київ: Видавничий центр КНЛУ, 2003.

Чорновол, Галина. Новітня економічна термінологія та їі стилістичне вживання в сучасній українській мові (на матеріалі періодичних видань). Дис. ... канд. філол. наук: 10.02.01. Київ, 2004.

Чуєшкова, Оксана. Аналітичні номінації в економічній терміносистемі (структурнотипологічний аспект). Дис. ... канд. філол. наук: 10.02.01. Харків, 2002.

\section{References}

Bohdan Svitlana. "Regulative money in Lesia Ukrainka's Epistolary Texts". Linguostylistic Studies, iss. 6, 2017, pp. 33-53.

Volovyk, Larysa. Word-formation Potential of the Prefixal Verbs of the Economic Terms in Modern German: Structural, Semantic and Functional Aspects. PhD Thesis Abstract. Kherson, 2012.

Druzhbyak, Svitlana. Dynamics of Term-Building in Professional Economic Language: Structural, Semantic, and Functional Aspects (A Study of Lexicographical Sources and Contemporary German Periodical Press). PhD Thesis Abstract. Kyiv, 2010.

Kuznecova, Jera. "O principah i metodah vydelenija ob\#ema semanticheskih klassov russkih glagolov". Klassy i ih vzaimodejstvie. Sverdlovsk, 1979, pp. 5-12.

Kushmar, Lesia. The Vocabulary of the Economic sphere in the Ukrainian Language World. PhD Thesis Abstract. Luhansk, 2011.

Lotka, Olena. Anhlomovna terminolohiia finansovo-ekonomichnykh vzaiemyn. PhD Thesis Abstract. Kyiv, 2000.

Mykhalevych. Olha. Structure and Functions of Economic Vocabulary of the Second Half of the XX - the Beginning of the XXI Century. PhD Thesis Abstract. Lutsk, 2011.

Navalna, Maryna. "Hroshi mozhut "zghority", yikh mozhut i "zamorozyty" (semantychna dynamika diiesliv u suchasnii ukrainskii publitsystytsi)". Kultura slova, iss. 78, 2013, pp. 104-109.

Navalna, Maryna. Diieslivna leksyka sotsialno-ekonomichnoi sfery (na materiali movy zasobiv masovoi informatsii kintsia XX st.). Pereiaslav-Khmelnytskyi, 2002. 
Navalna, Maryna. "Semantyko-stylistychni vyiavy diiesliv ekonomichnoi sfery v movi suchasnoi hazetnoi periodyky". Movoznavchyi visnyk, iss. 8, 2009, pp. 326-35.

Podvoyska, Oksana. Social Market Ekonomy Terminology in Modern German Language: Nominative and Functional Aspects. PhD Thesis Abstract. Odesa, 2008.

Rudakova, Tetiana. The functioning of the English-speaking origin of social and economic vocabulary at Ukrainian mass media in the end of XX - the beginning of the XXI century. PhD Thesis Abstract. Luhansk, 2009.

Slovnyk ukrainskoi movy, edited by I. K. Bilodid. 11 vols. Kyiv: Naukova dumka, 1970-1980.

Stanovlennia ta normuvannia ukrainskoi ekonomichnoi terminoleksyky. Kharkiv, 2011.

Styshov, Oleksandr. Ukrainska leksyka kintsia KhKh stolittia (na materiali movy zasobiv masovoi informatsii). Kyiv: Vydavnychyi tsentr KNLU, 2003.

Chornovol, Galyna. Modern economic terminology and her stylistic function in Ukrainian language. PhD Thesis. Kyiv, 2004.

Chueshkova, Oksana. Analytical nominations in the economical terminological system (structural typological aspect). PhD Thesis. Kharkiv, 2002.

Стаття надійшла до редколегії 03.11.2019 